\title{
A Contextual Analysis of the Medical Negligence in Bangladesh: Laws and Practices
}

\author{
* Khandakar Kohinur Akter \\ Lecturer (Law), School of Social Science \\ Humanities and Language, \\ Bangladesh Open University.
}

\begin{abstract}
Medical negligence is a clear violation of right to health by a professional group who are actually on duty to protect when emergency strikes and the health rights are under threat. Medical negligence is lately a popular topic of attention and discussion in many developed states and consequently many of them have enacted and established separate Acts and courts to strengthen health care laws. However in Bangladesh there is no specific and comprehensive legislation to prevent medical negligence though many legal provisions are there under different statutes which are not precisely codified. This article in this background has made an effort to define medical negligence, present laws concerning medical negligence of Bangladesh with their major loopholes and lastly recommends some actions to come on strong preventing such violation of health-care rights.
\end{abstract}

\subsection{Introduction:}

Hippocrates, the great Greek physician who is known as the father of western medicine said "Whenever a doctor cannot do well, he must be kept A from doing harm." This certainly means that doctors are only to do good and act like a protector, that's why they are treated like savior next to God. It is the duty of the doctor to extend medical assistance to save the life of patients. On the outset, every doctor has professional, legal and moral duty towards his patients. A doctor must always maintain the highest standards of professional conduct and must bear in mind the obligation of preserving human life from the conception and even under threat. According to the World Medical Association Declaration of Geneva 1948, a member of medical profession shall solemnly pledge stating that health of the patient will be a doctor's first consideration. ${ }^{1}$ In contrast, deviation from such professional conduct narrowly amounts to medical negligence. In a broader sense, medical negligence connotes culpable carelessness in the field of medical science and it involves risk to the health and well being of an individual who entrusts his well-being into the hands

\footnotetext{
* Lecturer (Law), School of Social Science, Humanities and Language, Bangladesh Open University.

${ }^{1}$ World Medical Association (WMA) Declaration of Geneva,_Adopted by the General Assembly of the World Medical Association at Geneva in 1948, Wikipedia, The Free Encyclopedia, Available at <http://en.wikipedia.org/wiki/Declaration_of_Geneva\#cite_note-1 > Accessed on March 12, 2013
} 
of a medical professional. ${ }^{2}$ The rationale behind the medical negligence law is that ordinarily a medical man is not responsible for evil consequences of his patients as they are entirely beyond his will. But if the mistakes arise from his ignorance or want of skill, he is blamable in as far as he is the willful cause of such ignorance; he should have either known better or, not, knowing better, he should not have undertaken the case for which he knew he was not qualified. ${ }^{3}$ Additionally, everybody, and specially the professional man must be accountable and the law is one of the means whereby the accountability to the patients, his family and society is revealed and enforced. The law, necessarily, should help to create conditions congenial to the advance of medicine, to the benefit of the patient, to the protection of the doctor and to the good of the community. ${ }^{4}$ So the law should also be clear, comprehensive, balanced, flexible and facilitating.

In Bangladesh, due to the absence of proper and effective law, the medical professionals are taking the full advantage of their professional indemnity and they just don't even feel that they are also a subject to law. This situation is deteriorating day by day as they give much time in their personal clinics or chambers for higher income and have a little time in hand while treating a patient. Occurrences of medical negligence can easily be noticed by the newspaper reports or through different TV channels almost in every month. Sometimes allegations are made by the families of the dead against such negligence that gets much media attention ${ }^{5}$. But unfortunately nothing happens later. It may be mentioned that medical errors are seen in Bangladesh mostly as active errors by doctors, nurses or other workers, such as giving the wrong amount of medication during an emergency procedure; and rest as dormant errors, such as poor equipment maintenance or design, or poorly organized health care delivery, such as failing to adequately follow up on a patient's diabetes or high blood pressure. ${ }^{6}$ While active errors are usually detected quickly, systemic and latent errors are difficult to detect because they are beyond the control of individual care-givers.

Considering the perspective, initially this paper will portray the legal ambit of medical negligence, review the existing laws on medical negligence of Bangladesh and focus on the possible solutions to upgrade this unaddressed legal arena for common good of the public.

2 S.M. Masum. Billah, Right to Life: Judicare of Medicare: The Daily Star, 17 April, 2010

Alec Samuels, 'The Doctor and the Law' (1981) The Medico-Legal Journal, Vol-XLIX, Part- IV, 139

Ibid

5 The late film actor Manna's wife Sheli Quader blamed a city hospital for her husband's death in a news briefing at Dhaka Reporters' Unity in $5^{\text {th }}$ March 2008 stating that Manna died prematurely because of the negligence of United Hospital but hospital authorities rejected the charges of negligence of duty in medical treatment . For details, see <http://bdnews24.com/bangladesh/2008/03/05/wife-blamesmanna-s-death-on-hospital>

6 Interview taken of a patient under treatment in Jamalpur Sadar Hospital, Dated on $15^{\text {th }}$ August 2013 


\subsection{Methodology:}

In this article qualitative - descriptive study design was used. For finding out the actual legal protection that the laws of Bangladesh provide to medical negligence victims, it includes an examination of the factual background and the legal literature considers investigation and also the theoretical underpinnings for the study. Data's been collected from secondary sources and experiences of victims of medical negligence gathered from media reports and personal interviews.

\subsection{Theoretical issues of Medical negligence:}

In particular, in a malpractice suit, a professional person is negligent if harm to a client results from such an act or such failure to act, but it must be proved that other prudent members of the same profession would ordinarily have acted differently under the same circumstances. In Roman law, negligence is signified by the terms 'culpa' and 'negligentia'. Care or absence of ' negligentia' is 'deligentia'. The use of the word diligence in this sense is obsolete in modern English, though it is still retained as an archaism of legal diction. ${ }^{7}$ Negligence is culpable (punishable) carelessness - conduct which involves an unreasonably great risk of causing harm to another. It is the absence of such care as it was the duty of the defendant to use. ${ }^{8}$ There are certain literatures which deal with the duties of the medical practitioners and breach of under mentioned certain duties can amount medical negligence. ${ }^{9}$

Firstly, the doctor has to have the duty to exercise a reasonable degree of skill and knowledge. The duty of care arises simply by examining someone for signs of illness by accepting a patient onto a list of existing patients. He owes this duty even when patient is treated free of charge. Next in order, when a practitioner agrees to attend a patient, he is under an obligation to attend to the case as long as it requires attention. ${ }^{10} \mathrm{He}$ only can withdraw after giving reasonable notice. If he is unable to treat the patient when needed, he may provide a qualified and competent substitute doctor to give the services. The doctor moreover should give full instruction to his patients through the prescription about the use of medicines and diet. He should maintain the exact name, quantities and precise timing for taking medicines. Patients should be instructed regarding the adverse reactions and to stop the drug in case of reaction, and to approach the doctor immediately. ${ }^{11}$

${ }^{7}$ Fitzgerald PJ. Salmond on Jurisprudence. 14th Ed. London; Sweet \& Maxwell: 1966

8 Dr. Lavlesh Kumar, Medical negligence- Meaning and Scope in India (2011) 51(181) Journal Nepal Medical Association, 49-52.

9 Dr. K.S. Narayan Reddy, The Essentials of Forensic Medicine and Toxicology, A.P.509002, $13^{\text {th }}$ ed,2012-13,37-41

10 Dr. Laxman Balkrishna Joshi v. Dr. Trimbark Babu Godbole and Anr., AIR 1969 SC 128

11 A.S.Mittal v. State of U.P., AIR 1989 SC 1570 
To address medical negligence, principle of standard of care is also a leading principle to regulate doctor's professional etiquette. ${ }^{12}$ This principle has been settled down by the leading English case Bolam v Friern Hospital Management Committee. ${ }^{13}$ To define 'standard of care' McNair J said: 'The test is the standard of the ordinary skilled man exercising and professing to have that special skill. A man need not possess the highest expert skill at the risk of being found negligent. It is well established law that it is sufficient if he exercises the ordinary skill of an ordinary competent man exercising that particular art.

The Judiciary of India also has ascertained significantly and progressively certain constitutional elements of medical negligence through some judicial decisions. According to the rulings, inadequacy in diagnostic or treatment procedures ${ }^{14}$ lack of preparation for an operation, ${ }^{15}$ or failure to sterilize properly ${ }^{16}$ are considered as examples of medical negligence.

\subsection{History of Medical Negligence Laws:}

The principle that doctors and indeed all professionals should be accountable for their failure is entirely acceptable. However, the modes to rest this accountability of the professionals are diverse and various methods have been tried over the period of time. ${ }^{17}$ The oldest known source that mentions medical negligence in the Code of Hammurabi was developed by Babylon's, kings some twenty centuries before Christian era. It fixed the fees for the treatment and penalties for the improper treatment. Roman law was also designed to punish the medical wrongdoers with a lovely fascist flavor. Medieval law was equally hard on errant 'barbers and surgeons'. ${ }^{18}$

In the earliest Indian medical literature, the word "mithya" which means false, incorrect, wrong and improper, has been used to describe the negligent medical treatment. It is stated that the physicians who act improperly or for wrong treatment, they are liable to punishment and the quantum of punishment varies according to the status of the victim i.e. 500 panas. (pana means a silver coin). ${ }^{19}$

12 Jaising Modi, Modi's Medical Jurisprudence and Toxicology ,LexisNexis, New Delhi, 23th ed,2006, 154.

${ }_{13}$ Bolam v Friern Hospital Management Committee (1957)1 WLR 582

14 Dr. Kunal Saha v. Dr. Sukumar Mukherjee and Ors. III (2006) CPJ 142 (NC)

15 Dr. Ravishankar v. Jery K. Thomas and Anr, II (2006) CPJ 138 (NC)

16 Pravat Kumar Mukherjee vs. Ruby General Hospital and Ors, II(2005)CPJ35(NC)

17 K Mathiharan, State control of Medical Malpractice, Law \& Medicine, An annual publication of the Institute of Law and Ethics in Medicine, National Law School of India University, Bangalore, Vol4,1998,88

18 Robert S Toth, Medical Malpractice, Physician as Defendant, Legal Dynamics of Medical Encounters, American College of Legal Medicine, St. Lois, The CV Mosby Co. 1988,482-491

19 Modi, above note 12, 151. 


\subsection{National legal framework to prevent medical malpractice and negligence:}

Medical negligence is a grave violation of right to life and right to health where right to life and health are basic and fundamental human rights to survive ${ }^{20}$ and our national instruments have provided several provisions to guarantee right to life and health in their substantive text.

In national context, the Constitution of Bangladesh has declared 'right to life' ${ }^{21}$ as a fundamental right which signifies (a) adequate safe and clear food, (b) safe drinking water, (c) public health - sanitation, (d) fairly comfortable sleeping accommodation, (e) medicine and healthcare, and (f) security of life and property. Indeed, in its Fundamental Principles of State Policy, the State has been obligated to ensure the "basic necessities of life, including food, clothing, shelter, education and medical care and to 'raising of the level of nutrition and the improvement of public health'. Additionally constitutional remedies are entertained where health is in risk, under Articles 15, 18 read with Articles 31, 32, 44 and 102 as guards of citizen's health right, since it is primary duty of the state to raise the level of nutrition and improve the public health.

There is no particular Act on medical negligence in our country, but under different statutes some remedies are found. We hardly have the Law of Tort in Bangladesh as an Act but provisions are available and enforced under different Acts as discussed below. Firstly sections 304 A, 314,323-326 of the Penal Code 1860 provide punishments for causing death by negligence, death caused by act done with intent to cause miscarriage, punishment for voluntarily causing hurt and grievous hurt, voluntarily causing hurt and grievous hurt by dangerous weapons or means. Under the penal code, it is said that whoever causes the death of any person by doing any negligent act not amounting to culpable homicide shall be punished with imprisonment of either description for a term which may extend to five years, or with fine, or with both. ${ }^{22}$ The definition of negligent act has been given where it means doing an act negligently, without necessary cautions and with willful risk. ${ }^{23}$ Punishments are also found in sections 336-338 which are more connected to medical negligent cases. Anyone causes hurt or grievous hurt to any person by doing any act so rashly or negligently as to endanger human life, or the personal safety of others shall be punished with imprisonment of either description for a term which may extend to in respective of six months to two years, or with fine which may extend to five hundred and five thousand taka, or with both.

20 Soobramoney v Minister of Health (Kwazulu-Natal) (CCT32/97) [1997] ZACC 17; 1998 (1) SA 765 (CC)

${ }^{21}$ Article-32 of the Constitution of Bangladesh

${ }^{22}$ Section-304 of the Penal Code, 1860

${ }^{23}$ Rashidullah v. State 21 DLR 709 
In second place, The Medical and Dental Council Act 1980 provides that if any registered medical/ dental practitioner or registered dentist has been convicted of any criminal offence after due inquiry found guilty of infamous conduct in any professional respect by the

Council, the Council may in its discretion direct the removal of the name of the medical practitioner or dentist from the register. ${ }^{24}$ Here the word "Convicted" is obviously used in relation to a duly constituted court. However this provision is discretionary and pliable in practice. ${ }^{25}$

Next, the Consumer Rights Protection Act, 2009 can be also a wide legal forum to deal the issue of medical negligence. Medical negligence with special reference to the Consumer Rights Protection Act, 2009 has the same sanctity of protection and enforcement of rights of patients. ${ }^{26}$ This is because that a medical patient is considered as a consumer and the medical institutions or professionals are as service provider. This Act has dealt with the punishment of not selling or delivering the promised product or service. ${ }^{27}$ Further another punishment has been provided for the violation of the rules-regulation under this Act or law which can endanger the life or security of the consumer. ${ }^{28}$ Furthermore, the section which can further directly be connected to the medical negligence is section 53 which stated that if any service provider causes damage to money, health or life of service receiver by negligence, irresponsibility or carelessness, he will be punished with imprisonment for a term not exceeding 3 years, or with fine not exceeding 2,00,000 taka, or both. However these punishments are not adequate because the amount of fine is inconsistent to the loss or injury occurred by the service providers. ${ }^{29}$

Moreover, under the Contract Act medical negligence issue has been addressed which is though not appropriate because providing medical service and fulfillment of contractual obligations are totally different issues in nature. Under the Contract Act, 1872 it has been stated that when a contract has been broken, the party who suffers by such breach is entitled to receive, from the party who has broken the contract,

${ }^{24}$ Section 28 of The Medical and Dental Council Act, 1980

25 Bangladesh Medical and Dental Council-1980, Professional Ethics and Code of Medical Conduct, p1-8 Available At <http://www.bmdc.org.bd/docs/codeofmedicalethics.pdf> accessed on 20 June, 2013

26 Dr. Belal Hosain Joy, Health care laws in Bangladesh, 4 October 2011 ,Available at<http://www.scribd.com/doc/67389243/Healthcare-Laws-in-Bangladesh-Final>Accessed on 20 June, 2013

${ }^{27}$ Section-45 has dealt with the punishment of not selling or delivering the promised product or service that provides imprisonment for a term not exceeding 3 years, or with fine not exceeding 2, 00,000 taka, or both.

${ }^{28}$ Section-52 has dealt with the punishment of not selling or delivering the promised product or service that provides imprisonment for a term not exceeding 1 year or with fine not exceeding 50,000 taka, or both.

29 Ibid, above note 26 
compensation for any loss or damage caused to him thereby, which naturally arose in the usual course of things from such breach, or which the parties knew, when they made the contract, to be likely to result from the breach of it. ${ }^{30}$ However, it is difficult to prove the allegations under this Act .The compensation or damages being granted stand at a different footing. ${ }^{31}$

Recently in 2011 Bangladesh Government has adopted National health Policy though it mostly concentrates on strategic design for right to health, such as, to obtain massscale consensus and commitment to socio-economic, social and political development to facilitate appropriate implementation of the Health Policy or to prevent diseases and promote health to achieve the basic objective of 'Health for All'. Furthermore, it has been stated that an adequate procedure will soon be designed to strengthen accountability and ensure quick and strict legal disposal of cases relating to negligence of duties. ${ }^{32}$ But this policy merely focuses on provision of negligence against health rights and thus it ignores the prosecution and prevention of medical malpractice.

Now out of the law book, if we go for a reality-check the situation is serious and dreadful. Ain O Salish Kendro (ASK), leading human rights NGO in Bangladesh, had discovered 504 specific medical negligence cases that happened in between June 1995 to September 2008, most of the narratives are sadly disappointing and sketch the horrendous picture of our state and standard of medicare. ${ }^{33}$ Moreover incidents of maximum number remain unreported. In our country, there are certain hindrances in the way of implementing the above mentioned laws relating to medical negligence and resultantly medico-legal cases can hardly be disposed of in a proper way.

\subsection{Problems of existing laws dealing with medical negligence in Bangladesh:}

Currently Bangladesh regulates medical negligence by way of different statutes which directly or indirectly prosecutes the wrongdoers as mentioned earlier. However there is no full-fledged legal forum to address the issue of medical negligence and most often people are not willing to seek redress of their grievances. The major problems of current laws are as follows:

\subsection{Absence of specific enacted laws:}

There are provisions in different statues but they are not proper and codified so the victims get confused in making decision that to which court they should go or under which Act they can institute a suit against medical wrongdoers. As instance,

\footnotetext{
${ }^{30}$ Section- 73 of the Contract Act, 1872

${ }^{31}$ Prof. SK Verma, Legal Framework for Health Care in India, Indian Law Institute Publication, $1^{\text {st }}$ ed, 2002, 158

32 Bangladesh Health Policy, Wikipedia, the free encyclopedia, Available at $<$ http://en.wikipedia.org/wiki/Bangladesh_health_policy> Accessed on 23th July.

${ }^{33}$ Billah, above note 2
} 
sometimes criminal cases are filed under the Penal Code which is not appreciable, because allegations do not mean that the doctors are guilty, so it would be a trouble for the doctors if criminal cases are filed against them. On the other hand, civil courts can not punish the defendants; they only have the authority to ascertain the amount of damages. Even under the Consumer Protection Act, suit can be instituted for medical negligence. So it can cause multiplicity of suits. It must be mentioned here that recently an attempt has been taken by the Law Commission of Bangladesh; it has come up with a proposal to make legislation on the point in order to address the widespread allegations of medical negligence in the country. ${ }^{34}$ Law commission's proposal nonetheless is based on a single basic premise to raise the standard of health service for the people without obviating the interest of the professionals and it is undoubtedly a good suggestion.

\subsection{Higher Court Fee:}

Generally to file a suit in a court needs a large scale of money along with higher fees which is not affordable by the poor litigant in Bangladesh. That's why victim often does not seek assistance from legal procedure. However in our neighboring country India, no court fees is required to institute a suit of medical negligence under Consumer Protection Act which encourages people to go to the court for speedy and effective redressal.

\subsection{Difficulties regarding Proof of negligence:}

The burden of proof regarding negligence issue goes on the shoulder of the complainant and if he fails to produce material evidence in the court that shows improper treatment on the part of the medical professional then no legal remedy will be available. And it becomes hard as due to the technicality of medical issues a doctor is required to prove the negligence of another doctor against whom a charge for negligence has been brought. But generally a doctor is not willing to provide information against another doctor as they belong to same profession. Even the medical institutes also deny providing necessary papers to the patients. Consequently, in the absence of the necessary documents and evidences; it becomes very difficult to prove a case of negligence. ${ }^{35}$ Most cases in Bangladesh the concerned medical institutions deny to provide them unless the judicial court orders to do so.

\subsection{Incompetency of the judges:}

In Bangladesh, judges are only trained to handle cases with traditional issues and medical negligence cases are of special in nature that needs additional expertise.

${ }^{34}$ S.M. Masum Billah, Law Commission's proposal of making medical negligence law, The Daily Star, April 20, 2013

35 S. Damayanti, What is medical negligence? What are the standard of care principles, 15 July 2011, Available at < http://pharmacyzoneustc.blogspot.com/2011/07/part-vi-implementation-of-existinglaws.html>Accessed on 21 June 2013 
Because of the technical nature of medical issues, the judges sometimes may not be considered as competent persons and to decide what is reasonable and what is not in particular case. ${ }^{36}$ A probable solution to this problem could be to allocate this function to medical experts and regulatory bodies who are more equipped to handle the case.

\subsection{Incompetent Medical Regulatory Bodies monitoring Private and Public hospitals:}

In Bangladesh, The Bangladesh Medical and Dental Council (BMDC) is empowered to take disciplinary action and to suspend or withdraw recognition of any institute and the qualifications conferred by it if its functioning is found to be substandard. ${ }^{37}$ To add, it is the only authority to regulate and control the professional conduct of the doctor and to take appropriate actions in the case of the negligence. But the actions taken by the Council are very few. ${ }^{38}$ Another problem is that the BMDC is subject to some limitations while exercising disciplinary function because its jurisdiction is limited to the doctors who are practicing privately or who are the employees of private clinics. In such a case only the Director General of Health or Health Ministry can take action, but they rarely exercise their function in this regard. ${ }^{39}$ Even recently the Law Commission acknowledged the fact that the BMDC's power is very confined to address the 'negligence' issue. ${ }^{40}$

\subsection{Complexity of Action under Consumer Protection Law:}

Though under the Consumer Protection Act, 2009 remedies are found for medical negligence but the process of instituting a suit is very complex. As example, if a consumer wants to lodge a complaint on such purpose, first he has to lodge a complaint before the Director General or authorized person of the department within 30 days of accrual of the cause of action. ${ }^{41}$ And the magistrate will not take cognizance of any offence if charge sheet is not submitted before him by the Director General or authorized person of the department within 90 days of lodging complaint. ${ }^{42}$ It means even if a consumer suffers from any loss, he can't file a complaint directly to the Magistrate. So consumer often does not show his interest as

36 Sultana Nishat, "Medical Negligence in Bangladesh; An Introduction”, Law Vision, Issue: 9 Department of Law, University of Chittagong, (2004-2005), 52.

37 Health ethics in six SEAR countries, World Health Organization (WHO), Health Ethics in South-East Asia,1991, Available at< http://www.hf.uib.no/i/filosofisk/seahen/vol1rev3.PDF>Accessed on 22 June 2013

38 Damayanti, above note 35

39 Ibid

40 Billah, above note 34

41 Section- 60 of the Consumer Protection Act, 2009

42 Section- 61 of the Consumer Protection Act, 2009 
this procedure takes a long time. On the other hand, in cases of private sectors, the Director general has the power to find out defects and lacking by checking the healthnursing care but will not take any preventive measure, he will only inform the secretary, Health Ministry and the Director General of the Health Directorate. ${ }^{43}$ So it is a big obstruction in punishing medical professionals working in private sector that's why the occurrences of professional negligence in private clinics are increasing day by day.

\section{7. Lack of public awareness:}

In Bangladesh, people are not aware of their health care rights and they even are not familiar with the concept of medical ethics. Again the government does not show much interest to circulate information relating to medical ethics or professional negligence, only when a big incident happens, then we find some articles on newspapers and reports on different TV channels. But no awareness- building programmes are found unfortunately.

\subsection{Recommendations:}

Though medical malpractice is responsible for the violation of right to health, most often the perpetrator, i.e., medical practitioners involved in such cases almost always get away. Lack of comprehensive legislation on medical negligence law, complexity of existing laws dealing with negligence, lack of public awareness are main drivers behind the issue. In this regard, this article proposes the following suggestions.

\subsection{Enactment of a separate special law relating to medical negligence:}

In Bangladesh, it is high time to enact a separate law to address the issue of medical negligence ascertaining a proper definition of the term 'medical negligence' with its nature and uniqueness. This arena stays unnoticed for a long time whereas separate and effective laws have been incorporated in the legal system of some developed countries and they are getting full advantages of it. Furthermore, the Law commission of Bangladesh has recently explained why a separate law is inevitable as the prevailing penal law is either trivial or vexatious. Additionally the laws of torts, being a product of common law, swims in a grey area in Bangladesh, as a result, in absence of specific legislation, strong case law jurisprudence has not been molded. ${ }^{44}$

43 Section-73 of the Consumer Protection Act, 2009

${ }^{44}$ Billah, above note 34 
In connection to that it can be mentioned that the state is under an international obligation to adopt appropriate legislative, administrative, budgetary, judicial, promotional and other measures to fully realize the right to health, which includes proper health care facilities and services. Additionally, victims deprived of right to health should be entitled to adequate reparation, which may take the form of restitution, compensation, satisfaction or guarantees of non-repetition. ${ }^{45}$

To add, a specific and comprehensive Act always helps the victims to get legal remedy in a shortest possible time with a procedure easily understandable and accessible. It can be noted as an example that in UK, the cases on medical negligence are tried under a distinct Act which proposes a redress package that includes an offer of compensation, explanation, apology and report of action to prevent similar occurrences. ${ }^{46}$ This Act has got much credit by the aggrieved, jurists and lawyers in dissolving medical negligence litigation properly. Even in Bangladesh the family courts have been established under the Family Courts Ordinance 1985 and the purpose of establishment of such courts was to ensure a quick, effective and amicable disposal of some of the family matters, which the traditional civil courts had failed to successfully deal with. Likewise, an enactment should be made by our legislature as early as possible for solving the cases relating to medical negligence efficaciously.

\subsection{Establishment of Health court:}

The concept of health court is comparatively new but it is now being appreciated by many progressive states. Health courts are proposed specialized courts for handling medical malpractice claims and they are characterized by the use of specially trained adjudicators, independent expert witnesses, and predictable damage awards. ${ }^{47}$ Moreover, in health courts, expert judges with special training would resolve healthcare disputes. They would issue written rulings providing guidance on proper

45 Fact Sheet no.31 on the Right to Health, Office of the United Nations, UN Office of the High Commissioner for Human Rights (OHCHR). Publication Date, June 2008, Available at

$<$ http://www.ohchr.org/Documents/Publications/Factsheet31.pdf > Accessed on $20^{\text {th }}$ September, 2013

46 The NHS Redress Act ,2006

${ }^{47}$ Health court - Wikipedia, the free encyclopedia, Available At <en.wikipedia.org/wiki/Health_court> Accessed on 12th September 2013 
standards of care. These rulings would set precedents on which both patients and doctors could rely. ${ }^{48}$

However research and resource mobilization is still required to set up health court in Bangladesh. The reasons for supporting it are firstly, Bangladeshi courts are overburdened with many civil and criminal cases and medical negligence case may be a hardship on them. Additionally, health courts are seen as more speedy and accurate to determine whether a plaintiff's injury was the result of a medical error or simply an adverse outcome. Secondly, health courts are more efficient that ensure expert panel of judges, lawyers for both parties. And thirdly, the courts are competent and authorized to provide necessary directions and precedents for further use. Though it may not be easy for the government to establish health courts without prior assessment and preparation, but they must keep in mind that health-care is one of the basic needs that deserve paramount consideration.

\subsection{Effectiveness of the consumer protection laws:}

Until a new Act is made, some amendments need to be brought in Consumer Rights Protection Act. The Act is not sufficient because the term 'medical profession' has not been inserted expressly in section-2.In this regard, it can be mentioned that in India the term has been added in section-2 (1) (o) of the Consumer Rights Protection Act, 1986. In 1995, the Supreme Court of India in a case ${ }^{49}$ decisively included the health profession as a subject matter of their consumer protection law. ${ }^{50}$ Indeed, this term should be included in our Act so that it becomes definite that the victims suffered through medical wrongs need to go to the consumer court and seek remedy under this Act. Though there is a criticism that whether medicare is to be regarded as merely a product or not but it has tremendously helped to tune some innovative justicing in case of medical negligence in our neighboring country India where medical negligence litigation is credited with bringing about safer practices in the health care provisions. ${ }^{51}$ To note, Dr. Faustina Pereira, renowned human rights activist and Advocate, also puts a great emphasis on a Consumer Protection Act on such issue, which is in the same league as the Right to Information Act. ${ }^{52}$ So amendments should be made in the Consumer Protection Act of Bangladesh to make it effective and adjustable to medical negligence litigation.

${ }^{48}$ Establish Health Courts, Common Good, Available at www.commongood.org/pages/establish-health courts Accessed on $12^{\text {th }}$ September 2013

${ }^{49}$ Indian Medical Association v. VP Shantha 3 CPR (1995) 412

${ }^{50}$ Modi, above note 12,157

${ }^{51}$ Billah, above note 34

${ }^{52}$ Hana Shams Ahmed, Changing Face of Health care, 20 April 2008, Available At $<$ http://hanashams.wordpress.com/2008/04/25/health-care/> Accessed on 13 ${ }^{\text {th }}$ August,2013 


\subsection{Ensuring accountability in medical administration, providing legal support and setting up effective complaint mechanism:}

Investigation of procedure to uncover the patient's complaints i.e. suggestion box, patient satisfaction surveys etc. must be monitored by the administration of the public and private medical institutions. Moreover, the patient or guardian should be briefed about the illness, treatment protocol, and the conversation with the patient should be documented in the patient's chart. This may later become evidence of the statue of limitations. ${ }^{53}$ That's how an effective complaint mechanism can be established. And the regulatory bodies i.e. Bangladesh Medical and Dental Council (BMDC) and the Ministry of Health need to be austere in monitoring the complaint mechanism which will ensure the accountability of those institutions. As instance, in 2008 the Ministry of Health established 'Monitoring and Supervisory Committee' in response to complaints from patients and 104 personnel in government hospitals found responsible for mismanagement and corruption leading to the sufferings of the patients were penalized ${ }^{54}$ which was a praise-worthy action taken by the government.

\subsection{Confirming availability and convenience of litigation:}

Under the present situation when an injured party goes to the court for instituting a suit on medical negligence, he must pay higher court fees which should be minimized. Moreover, it becomes difficult for him to prove his case as the medical institutions are not willing to provide necessary information. In the case, The Right to Information Act, 2009 can be a legal tool to ensure access to information in regard to medical issues. Moreover, amendments should be made in the Medical and Dental Council Act 1980 inserting the provision imposing duty on the physicians to maintain and preserve medical records and make them available to the patients or his relatives when requested. So necessary steps should be taken by the government to remove such complexity and make the way of redressal smooth and convenient to the party suffered.

\subsection{Ensuring effective redressal from the judiciary by competent judges:}

The courts can play an effective role to punish the negligent medical professionals by their rulings and precedents. Both by the trial courts and the High court (under writ jurisdiction) can pass judgments to secure the health care laws and in cases of breach of duty, courts must pronounce rigid and hard-line judgments as it is the constitutional duty of the court to protect right to life and right to health of the people. As instance, the High Court recently issued a rule against the alleged doctor, Home Secretary, Health Secretary and Inspector General of Police asking to reply to the rule why not to follow the instructions relating to the investigation and arrest in

53 Taha Nazir and Syed Muzzammil Masood Zaidi, Review of the basic components of clinical pharmaceutical care in Pakistan ,School of Pharmacy, The University of Lahore, 2011

54 "Government concerned at the quality of services at government hospitals", The Daily Ptothom Alo, 22 September, 2008 
the case against the doctor under section-304 (a), it is queried. ${ }^{55}$ To add, recently the Supreme Court of India has awarded a whopping Rs 5.96 crore as compensation to be paid by Kolkata- based AMRI Hospital and three doctors to a US-based Indian-origin doctor for medical negligence which led to the death of his wife in $1998 .{ }^{56} \mathrm{This}$ sort of exemplary court's rulings can be set as judicial precedents to prevent such violation of health care rights and to prosecute the wrongdoers through judicial process.

\subsection{Providing information about Medical ethics to professionals, patients and public at large to build awareness:}

The 'Code of Medical Ethics' has been published by Bangladesh Medical \& Dental Council in 1983 but the general public including patients are not aware of it. There should be enough publication about these documents by the Ministry of Health and Social Welfare so that the patients do know about the rights and duties and responsibilities of a medical practitioner under this Code. It can be noted that in Canada, statistics found that due to the recent mass circulation of awareness building programmes relating to the duties and liabilities of the doctors and patients, the number of medical negligence cases have been decreased in number. ${ }^{57}$

Furthermore, an awareness raising and training program may be taken for the nurse and ward boy of the hospitals, clinics and for all institutions relating to health care regarding the rights of the patients. Health planners, policy-makers and implementers should give priority to ethical issues in medical and allied education as well as medical practice. Awareness programmes can be circulated through newspapers and different tv channels to build awareness among the public at large.

\subsection{Participation of other institutions:}

In Bangladesh, though National Human Rights Commission (NHRC) is working on such issue ${ }^{58}$ but it must multiply its efforts for monitoring the health services in public and private hospitals in a regular basis. Also the consumer forums, patients' rights associations or similar institutions should address such violations and play the role of a watchdog. Further, from a recent time certain law firms like The Lawyers and Jurists, Islam and Associates, S. Ahmed and Associates are working on medical negligence cases. Also some well-known NGO's like Ain O salish Kendra (ASK), BLAST have done commendable paper works on this issue. Their combined force can make the situation far better than the past. Therefore, NHRC, law firms and the

${ }^{55}$ High Court rules against doctor to take action, Bangla News 24, September 14,2013

${ }_{56}$ SC orders Kolkata hospital to pay Rs 5.96 crore for medical negligence, Times of India, 24 Octeber, 2013

57 Medico-Legal Handbook for physicans in Canada, 7th ed., 2010, Available At <http://www.cmpaacpm.ca/cmpapd04/docs/resource_files/ml_guides/com_medico_handbook-e.cfm>Accessed on 24 th July 2013

58 NHRC team to visit hospitals to monitor services, The Daily Star, 15th September, 2010 
NGOs should provide legal help to the litigants and conduct nationwide formal and non-formal programmes to step forward preventing such violation of human rights.

\subsection{Conclusion:}

Medical negligence laws are to protect the patients from violation of their right to health and to preserve health care laws. Additionally it ensures to punish the medical professionals doing breach of professional duties intentionally. In this article, an attempt has been made to address the present existing legal provisions on medical negligence in Bangladesh. It also identifies the major shortfalls of such provisions. However, it must be admitted that the laws are not proper and adequate to respond this problem.

It is also known that, the state is under constitutional obligation to preserve and enforce the rights of the people and to meet the basic necessities of them including health care. In connection to that this paper also concluded with some recommendations that should be effectually considered so that the state can offer surety of improvement to the patients in health care delivery system addressing common good of the public health. The recommendations include enactment of a comprehensive law on prosecuting medical malpractice and establishment of health court. Simultaneously establishing effective complaint mechanism, mass training and awareness raising program are also suggested with a view to mobilizing information to doctors, nurses, and patients on the effects and redress of medical malpractice in Bangladesh. 